\title{
Üniversite Öğrencilerinin Matematik Problemine iliş̧kin Algılarının Metafor Yoluyla Analiz Edilmesi
}

Tuğba UYGUN, Arş. Gör. Dr., Bartın Üniversitesi, Illköğretim Bölümü, tugbauygun42@gmail.com

Burçin GÖKKURT, Yrd. Doç. Dr., Bartın Üniversitesi, Illköğretim Bölümü, gokkurtburcin@gmail.com Neslihan USTA, Yrd. Doç. Dr., Bartın Üniversitesi, Illköğretim Bölümü, neslihanusta74@gmail.com

Öz: Bu çalışmanın amacı, üniversite öğrencilerinin matematik problemine yönelik algılarını metafor yoluyla incelemektir. Veri toplama aracı olarak, çalışmada Sezgin-Memnun (2015)'un matematik problemiyle ilgili hazırlamış olduğu form kullanılmıştır. Bu çalışmanın katılımcılarını, Batı Karadeniz Bölgesi'nde yer alan bir devlet üniversitesinin ilköğretim matematik ve sınıf öğretmenliği programlarında öğrenim gören toplam 269 (204 Kız, 65 Erkek) öğrenci oluşturmaktadır. Çalışmadan elde veriler, öğrencilerin yazılı açıklamalarından ve bunlar arasından seçilen 16 öğrenciyle yapılan görüşmelerden elde edilmiştir. Çalışmada, nitel araştırma yaklaşımına dayalı olgu bilim yöntemi kullanılmıştır. Verilerin analizinde içerik ve betimsel analiz teknikleri kullanılmıştır. Çalışma sonunda, öğretmen adaylarının matematik problemine ilişkin 11 farklı kategoride metaforlar geliştirdikleri ve bunlar arasında en çok üretilen metaforun yığılmalı yapı /çözüm yapısı kategorisinde olduğu görülmüştür. Ayrıca çalışmada, sınıf öğretmenliği programında öğrenim gören öğrencilerin, matematik problemine ilişkin görüşlerinin, matematik öğretmenliği bölümünde öğrenim gören öğrencilere göre olumsuz olduğu tespit edilmiştir.

Anahtar Kelimeler: Matematik problemi, metafor, üniversite öğrencileri.

\section{Analysis of the Perceptions of the University Students about Mathematics Problem through Metaphor}

\begin{abstract}
The purpose of the current study was to examine the perception of university students about the mathematics problem through metaphors. The form designed by Sezgin-Memnun (2015) about mathematics problem was used as the instrument to collect data in the study. The participants of the study were composed of 269 (204 female, 65 male) students enrolled in the programs of elementary mathematics education and primary education at a university in North West part of Turkey. The data were collected through the written descriptions of the participants about this form and the interviews made by 16 participants. The study was designed based on phenomenology as a qualitative research method. The data were analyzed based content and descriptive analysis techniques. At the end of the study, it was observed that the participants formed 11 different categories of metaphors about mathematics problem and the most commonly formed metaphor was cumulative structure/solution structure. Moreover, it was found that the perception of the participant at the program of primary education formed more negative views than the participants at the program of elementary mathematics education.
\end{abstract}

Key Words: Mathematics problem, metaphor, university students 


\section{GíRiş}

Matematik, bilgiyi işlemeyi, üretmeyi, tahminlerde bulunmayı ve matematiksel dili kullanarak problem çözmeyi içerir. Matematik dersi öğretim programında problem çözmeye ayrı bir önem verilmiş (Baykul \& Sulak, 2006) ve problem çözme, matematik dersinin amaçları arasında yer almıştır (Baykul, 2009). Bu nedenle problem çözme becerisi, ilkokul, ortaokul ve ortaöğretim matematik dersi öğretim programlarının tümünde öğrencilere kazandırılması gereken temel becerilerden biri olmuştur (MEB, 2013a, 2013b, 2015). Problem çözme, yeni durumlar ile var olan durumlar arasındaki ilişkileri ortaya koyma ve belirli bir sonuca ulaşmaktır (Pesen, 2003). Problem çözme, sadece bir matematik problemin çözümünü yapmak olarak görülmemelidir. Problem çözme, aynı zamanda yeni durumlarla karşılaşıldığında bu durumlara işe yarar çözümler bulmak anlamına gelmektedir (Gail, 1996).

Problem çözmeye bağlı olarak alan yazında pek çok araştırmacı problemi farklı şekillerde tanımlamışlardır. Problem, daha önce karşılaşılmayan bir zorluk, aşılması gereken alışılagelmedik bir engel olarak tanımlanmıştır (MEB, 2015). Bloom ve Niss (1991), problemi açık uçlu soruları içeren, kişide merak uyandıran ve bu soruları çözmek için gereken işlem ve yöntem bilgisinin bilinmediği durum olarak nitelendirirken, Olkun ve Toluk (2004), problemi bireyde problemi çözme isteği uyandıran, çözüm süreci hemen akla gelmeyen bireyin bilgi ve deneyimlerini kullanarak çözebileceği durumlar olarak nitelendirmişlerdir. Özsoy (2005), problemi, en genel anlamda karmaşık veya sonucu belirsiz bir durum olarak belirtmiştir. Lester (1983), bireylerin bir çözüm bulmak istedikleri ya da çözüme intiyaç duydukları durumlar olarak ifade etmiştir. Bu tanımlar dikkate alındığında, problemin sadece matematikle ilgili olması gerekmediği ve problemin "bireyde merak uyandıran, çözüm sürecinin bilinmediği ve cevabı bulunması gereken durum" niteliklerine vurgu yapıldığı görülmektedir. Bu nedenle problem çözme sadece matematik programında değil, diğer derslerin öğretim programlarında yer almıştır. Bu bağlamda, problem, birçok araştırmacı tarafından üzerinde çalışılan bir konu olmuştur (Brown, 2003; Çelik \& Güler, 2013; Cai, 2003; Crespo, 2003; Crespo \& Sinclair, 2008; Dinç-Artut \& Tarım, 2009; Gökkurt \& Soylu, 2013; Gökkurt, Örnek, Soylu, \& Hayat, 2015; Gökkurt, Koçak, \& Soylu, 2015; Kılıç, 2014; Olkun, Şahin, Akkurt, Dikkartın, \& Gülbağcı, 2009; Willoughby, 1985). Bu araştırmada çalışmanın amacı doğrultusunda problem kavramı matematiksel problem anlamında kullanılmıştır.

Bireylerin matematik problemine bakış açıları, kendisi hakkındaki inançlarından ve geçmiş yaşantılarından etkilenmektedir. (Fitzpatrick, 1994). Bireylerin probleme yaklaşımları farklılık göstermektedir (Yıldırım, Hacıhasanoğlu, Karakurt, \& Türkleş, 2011). Öğrencilerin matematik problemine ilişkin olumlu veya olumsuz düşüncelerini saptamak önem taşımaktadır. Bireylerin probleme ilişkin algılarını ortaya çıkarmak için başvurulacak en iyi yollardan biri sahip oldukları metaforlardır. Çünkü metaforlar, olgular hakkında düşüncelerimizi yansıtan, onlara yön veren en güçlü zihinsel araçlardan biridir (Saban, 2004). Metaforlar, bilinmeyeni ifade etmek ve olayların oluşumunu benzetmelerinden yola çıkarak bilinir hale getirilmesini sağlamaktır (Balcı, 2003). Metafor bir nesnenin niteliğini, özelliğini daha iyi açıklayabilmek için başka nesne ya da eylemden yararlanarak onu anımsatma yoluyla oluşturulur (Morgan, 1997'den aktaran Özdemir \& Akkaya, 2013). Metaforlar bir söz dizini değil aynı zamanda bir düşünce biçimidir (Lakoff \& Johnson, 2005). Bireylerin hayatı, çevreyi, olayları ve nesneleri nasıl gördüklerini, benzetmeler kullanarak açıklamaya çalıştıkları bir araç (Cerit, 2008), insanların çevresindeki olayları anlamlandırmalarına ve yapılandırmalarına yönelik güçlü bir zihinsel haritalama ve modelleme mekanizması (Arslan \& Bayrakçı, 2006) olarak tanımlanmaktadır. 
Eğitim süreçlerini anlamlandırmada etkili bir araç olarak görülen metafor için (Balcı, 1999), alan yazında pek çok çalışmaya rastlanmaktadır. Bu çalışmalar detaylı incelendiğinde, ortaokul öğrencilerinin (Şengül \& Katrancı, 2012), ortaokul ve lise öğrencilerinin (Gür, Hangül, \& Kara, 2014) ve matematik öğretmeni adaylarının matematik (Güler, Akgün, Öçal, \& Doruk, 2012), lise öğrencilerinin akılı tahta (Aktürk, Mihçi, \& Çelik, 2015) ve sınıf öğretmenlerinin problem kurma (Kılıç, 2014) kavramına ilişkin sahip oldukları metaforları inceleyen çalışmaların olduğu görülmektedir. Bununla birlikte, ortaöğretim öğrencilerinin ve öğretmenlerinin okul ve ideal okula yönelik algıları (Akkaya, 2012), ortaokul öğrencilerinin matematik dersine ve matematik öğretmenine yönelik algıları (Ada, 2013, Güler, Öçal, \& Akgün, 2011, Şengül, Katrancı, \& Gerez-Cantimer, 2014) ve sekizinci sınıf öğrencilerinin SBS'ye yönelik algıları (Karadeniz, Er, \& Tangülü, 2014) analiz edilmiştir.

Literatürde metaforun veri toplama aracı olarak kullanıldığı çalışmalara da rastlanmıştır (Chapman, 1997, 1998). Problem kavramıyla ilgili metaforik algıları üzerine yapılan çalışmalar dikkate alındığında ise, araştırmacılar ortaokul öğrencilerinin (Sezgin-Memnun, 2015) ve ortaokul matematik öğretmeni adaylarının problem kavramına (Baş \& Özturan-Sağırlı, 2016) ilişkin algılarını metaforlar yoluyla analiz etmişlerdir. Bu araştırmada yapılan araştırmalardan farklı olarak sınıf öğretmenliği ve ilköğretim matematik öğretmenliği programında öğrenim gören öğrencilerin probleme ilişkin sahip oldukları metaforların ortaya koyulması ve bu metaforların öğrenim gördükleri bölüme ve sınıf düzeylerine göre değişiminin incelenmesi amaçlanmıştır. Bu çalışmadan elde edilecek sonuçların hem sınıf öğretmenliği programında öğrenim gören öğrencilerin, hem de ilköğretim matematik öğretmenliği programında öğrenim gören öğrencilerin problem kavramına ilişkin sahip oldukları metaforları ortaya koyması, bu metaforların öğrencilerin öğrenim gördükleri bölüme ve sınıf düzeylerine göre değişip değişmediğinin incelenmesinin alana katkı sağlayacağı düşünülmektedir. Çünkü sınıf ve matematik öğretmenliği programında öğrenim gören öğrencilerin matematik problemi hakkındaki olumlu ve olumsuz düşüncelerinin anlaşılması neticesinde olumsuz düşünceye sahip olan öğrencilerin bu düşüncelerinin ortadan kaldırılması konusunda gerekli tedbirlerin alınması açısından önem arz etmektedir. Ayrıca farklı sınıf düzeylerinde ve farklı bölümlerde öğrenim gören öğrencilerin probleme ilişkin sahip oldukları metaforların bir arada incelenmesi, öğrencilerin problem çözme yaklaşımları konusunda ipuçları sağlayabilir.

\subsection{Araştırmanın Amacı}

Bu çalışmanın amacı, sınıf ve ilköğretim matematik öğretmenliği bölümünde öğrenim gören öğrencilerin "matematik problemine" yönelik algılarını metaforlar aracılı̆̆ıyla ortaya çıkarmaktır. Bu amaç doğrultusunda, aşağıdaki alt problemlere cevap aranmıştır:

1) Sınıf ve ilköğretim matematik öğretmenliği bölümünde öğrenim gören öğrencilerin matematik problemine ilişkin sahip oldukları metaforlar nelerdir?

2) Sınıf ve ilköğretim matematik öğretmenliği bölümünde öğrenim gören öğrencilerin matematik problemine ilişkin sahip oldukları metaforlar sınıf düzeyine göre nasıldır?

3) Sınıf ve ilköğretim matematik öğretmenliği bölümünde öğrenim gören öğrencilerin matematik problemine ilişkin sahip oldukları metaforlar öğrenim gördükleri bölüme göre nasıldır?

\section{YÖNTEM}

Bu çalışmada nitel araştırma yaklaşımına dayalı olgu bilim yöntemi kullanılmıştır. Olgubilim araştırmalar, bireylerin yaşadıkları ortamda karşılaştıkları olgularla ilgili olarak ne algıladıkları ve deneyimlerinin neler olduğu üzerinde durur ve bu yöntemi kullanan 
araştırmacılar bireylerle uzun görüşmeler yaparak, bireyin olguyla ilgili olan algısını ortaya koyma çalışırlar (McMillan \& Schumacher, 2010). Olgubilim araştırmalarda bireylerin bir olguyla ilgili tanımlamaları doğru veya yanlış olarak değerlendirilmez. Bu yöntemde, araştırılan olguyla ilgili olarak ortaya atılan tanımlar kategorilere ayrılır. Bu kategoriler, bireylerin ne düşündüklerini ortaya koymaya yardımcı olur (Koballa, Graber, Coleman, \& Kemp, 2000'den akt. Çekmez, Yıldız, \& Bütüner, 2012). Bu çalışmada, üniversite öğrencilerinin matematik problemini nasıl algıladıklarını ortaya çıkarmayı amaçladığından ve çalışmada veri toplama aracı olarak katılımcıların yazııı açıklamaları yanında görüşme tekniği kullanıldığından olgu bilim yöntemi tercih edilmiştir. Çünkü görüşmeler, genellikle olgu bilim araştırmalarda en yaygın kullanılan yöntemdir (Sart, 2015).

\subsection{Katılımcılar}

$\mathrm{Bu}$ araştırma, Batı Karadeniz Bölgesi'nde yer alan bir devlet üniversitesinde ilköğretim matematik ve sınıf öğretmenliği programının öğrenim gören toplam 269 (204 Kız, 65 Erkek) öğrenci ile yürütülmüştür. Katılımcıların seçiminde amaçı örnekleme yöntemi kullanılmıştır. Bu kapsamda katılımcıların ilköğretim matematik ve sınıf öğretmenliği programında öğrenim gören öğrencilerden seçilmesine dikkat edilmiştir. Bu iki bölümün seçilmesinin gerekçesi olarak problem çözme becerisinin her iki bölümün öğretim programında öğrencilere kazandırıması gereken temel beceri olması gösterilebilir. Nitekim bu öğretim sürecinde rol oynayan da sınıf ve ortaokul matematik öğretmenleridir. Bu kapsamda ileride bu mesleği yürütecek olacak öğretmen adaylarının matematiksel probleme karşı görüşlerini tespit etmek önem arz etmektedir. Çalışmanın katılımcılarının hangi sınıf düzeyinde ve bölümde öğrenim gördükleri Tablo 1'de belirtilmiştir.

Tablo 1. Katılımcıların Öğrenim Gördükleri Bölüme ve Sınıf Düzeylerine Göre Dağııımı

\begin{tabular}{|c|c|c|}
\hline Sınıf Düzeyi & імÖ & sö \\
\hline 1. Sinıf & 32 & 45 \\
\hline 2. Sinif & 37 & 41 \\
\hline 3. Sinif & 27 & 34 \\
\hline 4. Sinif & 33 & 20 \\
\hline Toplam & 129 & 140 \\
\hline
\end{tabular}

iMÖ: ilköğretim Matematik Öğretmenliği SÖ: Sınıf Öğretmenliği

Araştırmanın etiği gereği katılımcıların gerçek isimleri yerine ilköğretim matematik öğretmenliği bölümünde öğrenim gören öğrenciler için $M 1, M 2, \ldots \ldots . . . M 129, \quad$ sınıf öğretmenliği bölümünde öğrenim gören öğrenciler için S1, S2,..........S140 şeklinde kodlar kullanılmıştır.

\subsection{Veri Toplama Araçları}

$\mathrm{Bu}$ araştırmada, üniversite öğrencilerinin matematik problemine ilişkin algılarını metafor yoluyla tespit etmek için her katılımcıdan, Sezgin-Memnun (2015)'un çalışmasında kullandığı" Matematik problemi ... Gibidir, Çünkü ..." ifadeyi doldurmaları istenmiş ve sadece bir metafor üzerinde yoğunlaşmaları istenmiştir. Katılımcıların ilk boşluğa matematik problemi için bir metafor yazmaları, çünkü ifadesinden sonraki boşluğa da neden bu metaforu yazdıklarını açıklamaları istenmiştir. Çünkü her birey aynı metafora (mecaza) farklı anlamlar yükleyebilmektedir. Bu doğrultuda metaforun (mecazın) hangi amaçla kullanıldığı ancak "niçin" sorusunun yanıtıyla elde edilebilir (Yıldııı \& Şimşek, 2013). Bu sebeple metaforu hangi amaçla kullanıldığını anlamak için "niçin" sorusuna yanıt vermeleri istenir. Bu çalışmada öğrencilerin düşündükleri metaforu niçin ürettiklerini anlamak için "çünkü" ifadesinden sonraki boşluğa sebebini yazmaları istenmiştir. Katılımcıların bu ifadeyi tamamlamaları 8-10 dakika sürmüştür. Katılımcılar tarafından doldurulan yazılı açıklamalar "doküman" olarak araştırmacının temel 
veri kaynağını oluşturmuştur. Ayrıca, katılımcıların verdikleri cevapların daha iyi anlaşılması için sınıf ve matematik öğretmenliği programının her birinden sekiz öğrenci seçilerek toplam 16 öğrenci ile görüşme yapılmıştır. Katılımcılardan yaptıkları yazılı açıklamalarını detaylı olarak söylemeleri istenmiştir.

\subsection{Verilerin Analizi}

Bu çalışmada metaforlara ilişkin elde edilen verilerin çözümlemesinde Sezgin-Memnun (2015)'un kategorileri ve kodları kullanılarak betimsel analiz, araştırmacılar tarafından oluşturulan "Gerçek Durum/Sık karşılaşılan durumlar" gibi kodlar içerik analizi yapılmıştır. Yıldırım ve Şimşek (2013)'e göre betimsel analizde, veriler daha önceden belirlenen temalara göre özetlenir ve yorumlanır. Ayrıca çalışmada katılımcılardan doğrudan alıntılar verilerek çalışmanın ayrıntılı bir resmi sunulmuştur.

Çalışmada betimsel bir yaklaşımla fark edilemeyen kavram ve kategoriler için de içerik analizi tekniğine başvurulmuştur. Yıldırım ve Şimşek (2013)'e göre içerik analizinde, elde edilen ham verileri açıklayabilecek kavramlara ulaşmak temel amaçtır. Verilerin analizi dört adımda gerçekleştirilmiştir. Bunlar a) Metaforların belirlenmesi ve geçersiz metaforların elenmesi, b) Metaforların Sezgin-Memnun (2015)'un çerçevesine göre kodlanması ve bu kodlara girmeyen metaforların iki araştırmacı tarafından bağımsız olarak yeniden kodlanması d) Metaforların kategorileştirilmesi e) Çalışmanın güvenirliği için katılımcıların yazılı açıklamaları Miles ve Huberman (1994)'ın uyuşma hesabı kullanılarak iki araştırmacı tarafından birbirinden bağımsız

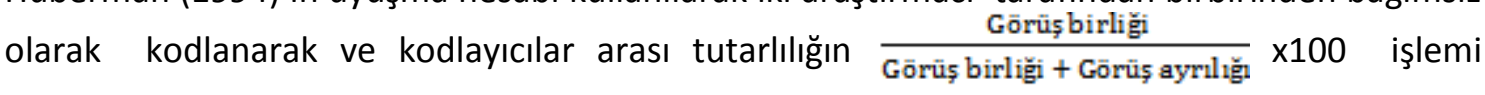
sonucunda 0.98 olarak hesaplanması.

Elde edilen verilerin analizi ve yorumlanması aşamasında öncelikle tüm metaforlar (geçerli, geçersiz) incelenmiş ve incelenen metaforlar arasından dört metaforun geçersiz olduğu görülmüştür. Bu metaforların geçersiz sayılmasının gerekçesi olarak metaforun konusu ile kaynağının arasında ilişkinin kurulamaması gösterilebilir. Çünkü Forcenville (2002) 'ye göre, herhangi bir şeyin metafor olarak kabul edilebilmesi için metaforun konusunun, kaynağının ve konusu ile kaynağı arasındaki ilişkinin kurulabilmesi gerekir. Örneğin öğretmen güneş gibidir denildiğinde metaforun konusu öğretmen, kaynağı güneştir. Metaforun kaynağından konusuna atfedilmesi düşünülen özellik ise güneşin çevreyi aydınlatması gibi öğretmenin de öğrencilerine bilgi sunarak onları aydınlatmasıdır. Ancak bu dört metaforun konusu ile kaynağı arasında anlamlı bir ilişki olmayıp gerekçesi açıkça yazılmadığından bu metaforlar çalışmaya dahil edilmemiştir. Ayrıca iki öğrencinin problemi herhangi bir nesneye benzetememesi ve cevap verememesinden dolayı iki öğrencinin yazılı açıklaması değerlendirilememiştir. Bu nedenle toplamda 269 öğrenciden 263 öğrencinin ürettikleri metaforlar çalışma kapsamında incelenmiştir.

\section{BULGULAR}

Bu bölümde araştırmaya katılan üniversite öğrencilerinin "matematik problemi" için ürettikleri metaforlar, ortak özelliklerine göre kategoriler altına yerleştirilmiştir. Elde edilen metaforların kategorilere ayrılmasında, öğretmen adaylarının metaforu niçin ürettiklerine "Çünkü" ifadesinden sonraki boşluğa yazdıkları açıklamalarına bakılarak karar verilmiştir. Tüm metaforlar, gerekçeleri dikkate alınarak incelendiğinde 11 farklı kategori altında toplanmıştır. Metaforların kategorilere dağılımına ilişkin yüzde, frekans değerleri okudukları bölüme göre her sınıf düzeyinde tablolar halinde verilmiş olup iki bölümde öğrenim gören öğrencilerin ürettikleri metaforlar karşılaştırılmıştır. 


\section{Ilköğretim Matematik Öğretmenliği Programında Öğrenim Gören Öğrencilerin Geliştirdikleri Metaforlara iliş̧kin Bulgular}

Tablo 2. Ilköğretim Matematik Öğretmenliği Programının Birinci Sıııfında Öğrenim Gören Öğrencilerin Probleme iliş̧kin Geliştirdikleri Metaforların Frekans ve Yüzde Dağılımı

\begin{tabular}{|c|c|c|c|}
\hline Sınıf Düzeyi & 1.sınıf & & \\
\hline Kategoriler & Kodlar & f & $\%$ \\
\hline $\begin{array}{l}\text { YığıImalı yapısı/ Çözüm } \\
\text { yapısı }\end{array}$ & $\begin{array}{l}\text { Yapboz(2), kaplumbağa(1), büyüyen çığ(1), Jenga(1), } \\
\text { anlaşılmayı bekleyen insan(1), karışık ip yumağı(1), } \\
\text { puzzle(4), evcil hayvan(1), bataklık(1), labirent(1), }\end{array}$ & 14 & 45.16 \\
\hline Zor/ Karmaşık & $\begin{array}{l}\text { Labirent(2), kadın(2), spagetti makarna(1), kördüğüm } \\
\text { ip(1) }\end{array}$ & 6 & 19.35 \\
\hline Emek/Beceri gerektirme & Bukalemun(1),düğümlü ip(1) & 2 & 6.45 \\
\hline $\begin{array}{l}\text { Karşıt kavramlar / olumlu- } \\
\text { olumsuz kavramlar }\end{array}$ & Düğüm(1), zeka küpü(1) & 2 & 6.45 \\
\hline Korkutucu /sıkıcı/gereksiz & Yaramaz çocuk(1) & 1 & 3.22 \\
\hline Eğlenceli & Oyun(2),bulmaca(2) & 4 & 12.90 \\
\hline Faydalı & Düğümlenmiş halat(1) & 1 & 3.22 \\
\hline Sonsuzluk & - & - & - \\
\hline Önemli/değerli & - & - & - \\
\hline Anlama/strateji kullanımı & Polo test oyunu(1) & 1 & 3.22 \\
\hline $\begin{array}{l}\text { Gerçek Durum/Sık } \\
\text { karşılaşılan durumlar }\end{array}$ & - & - & - \\
\hline TOPLAM & & 31 & 100 \\
\hline
\end{tabular}

-: İlgili kategoride ve kodda metafor üretilmemiştir.

Tablo 2'de verilen bilgiler incelendiğinde, birinci sınıf öğrencilerinin çoğunun yığılmalı yapısı/ çözüm yapısı (\%45.16) ve zor/karmaşık (19.35) kategorilerinde metafor ürettikleri görülmektedir. Yığılmalı yapısı/çözüm yapısı kategorisinde metaforu üreten öğrencilerin bazıları matematik problemini yapboza, karışık ip yumağına, puzzle gibi cansız nesnelere benzetirken, bazıları da evcil hayvan, kaplumbağa gibi canlı nesnelere benzetmişlerdir. Zor/karmaşık kategorisinde metaforu üreten öğrenciler ise labirent, kadın, spagetti, makarna, kördüğüm ip gibi nesnelerin özelliklerini dile getirerek matematik probleminin zor/karmaşık yapısına vurgu yapmışlardır. Bu iki kategoride üretilen örnek metaforlarla ilgili alıntılar şekil 1 'de verilmiştir.

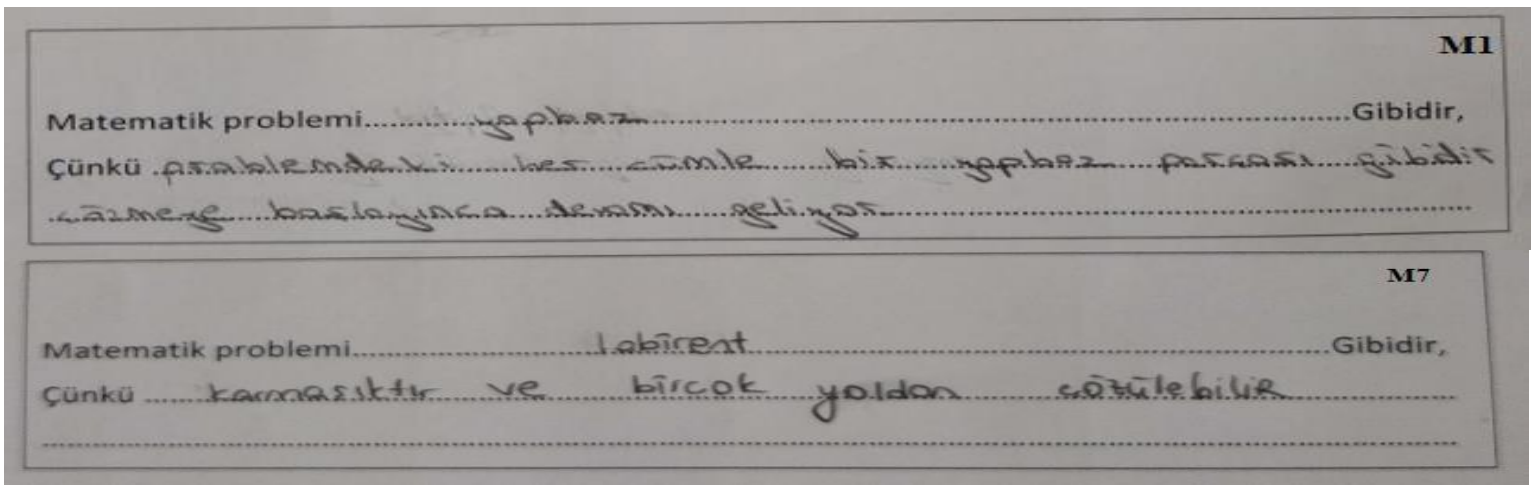

Şekil 1 M1'in ve M7'nin yığılmalı yapısı/ çözüm yapısı ve zor/karmaşık kategorilerinde ürettikleri metaforlar

Şekil 1 'den anlaşılacağı üzere $M 1$ 'in matematik problemini yapboza, M7'nin ise matematik problemini labirente benzettiği görülmektedir. Gerekçeleri incelendiğinde, M1'in problemin yapısına, M7'nin ise karmaşık yapısına vurgu yaptığı açıkça görülmektedir. Emek/ 
beceri kategorisinde metafor üreten iki öğrencinin ise problemin çözümü için uğraş gerektiren özelliğine odaklandıkları görülmektedir. Şekil 2'de verilen M10'nun alıntısı bu durumu en iyi şekilde örneklendirmektedir.

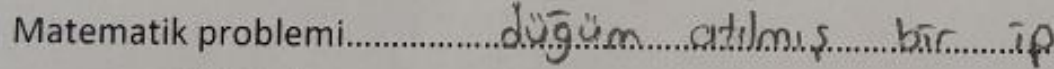
Gibidir

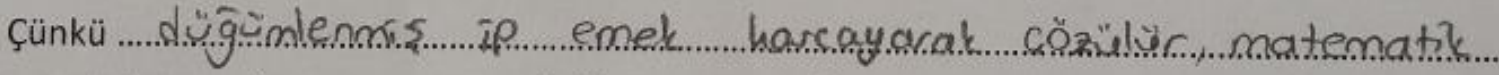

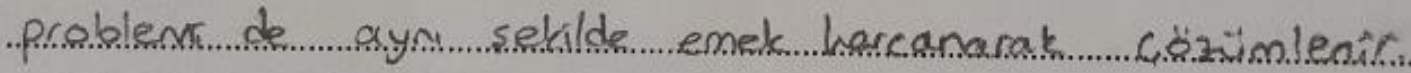

Şekil 2. M10’nun emek/beceri kategorisinde ürettiği metafor

Tablo 3. Ilköğretim Matematik Öğretmenliği Programının ikinci Sınıfında Öğrenim Gören Öğrencilerin Probleme ilişkin Geliştirdikleri Metaforların Frekans ve Yüzde Dağılımı

\begin{tabular}{|c|c|c|c|}
\hline Sınıf Düzeyi & 2.Sınıf & & \\
\hline Kategoriler & Kodlar & f & $\%$ \\
\hline Yığılmalı yapısı / Çözüm yapısı & $\begin{array}{l}\text { domino taşı (1), ağaç(1), jenga(1), tren (1), } \\
\text { merdiven (4), Labirent(1), yapboz(1), heyecanlı } \\
\text { film(1), kadın(1), puzzle(2), örüntülü işlem(1), koşu } \\
\text { parkuru(1), kördüğüm(1), ressamın boyası(1) }\end{array}$ & 18 & 50 \\
\hline Zor/ Karmaşık & Düğüm(1), erkek(1) & 2 & 5.56 \\
\hline Emek/Beceri gerektirme & $\begin{array}{l}\text { Gemici düğümü(1), yarış(1), çocuk(1),ekin ekme(1), } \\
\text { savaş(1), dolaşan kulaklık(1), düğüm(1), }\end{array}$ & 7 & 19.44 \\
\hline $\begin{array}{l}\text { Karşıt kavramlar / olumlu- } \\
\text { olumsuz kavramlar }\end{array}$ & $\begin{array}{l}\text { Tavus kuşu(1), yabancı şehir(1), şiir(1), acı biber (1), } \\
\text { hayat(1), }\end{array}$ & 5 & 13.90 \\
\hline Korkutucu /sıkıcı/gereksiz & - & - & - \\
\hline Eğlenceli & - & - & - \\
\hline Faydalı & - & - & - \\
\hline Sonsuzluk & Uzun yol(1), insan(1), & 2 & 5.56 \\
\hline Önemli/Değerli & - & - & - \\
\hline Anlama/strateji kullanımı & Zekâ küpü(1), & 1 & 2.78 \\
\hline $\begin{array}{l}\text { Gerçek Durum/Sık karşılaşılan } \\
\text { durumlar }\end{array}$ & Yaşam(1) & 1 & 2.78 \\
\hline TOPLAM & & 36 & 100 \\
\hline
\end{tabular}

-: ilgili kategoride ve kodda metafor üretilmemiştir.

Tablo 3'teki veriler incelendiğinde, ikinci sınıf öğrencilerinin büyük çoğunluğunun Yığılmalı yapısı / Çözüm yapısı kategorisinde metafor ürettikleri, çok az bir kısmının ise Zor/ Karmaşık, Sonsuzluk, Anlama/strateji kullanımı, Gerçek Durum/Sık karşılaşılan durumlar kategorisinde metafor ürettikleri görülmektedir.

Diğer öğrencilerin ürettikleri metaforlar incelendiğinde ise, öğrencilerin \%33.34'ünün emek/beceri gerektirme ve karşıt kavramlar/olumlu-olumsuz kavramlar kategorisinde cevap verdikleri görülmektedir. Karşıt kavramlar/olumlu-olumsuz kavramlar kategorisinde cevap öğrencilerden birinin cevabı Şekil 3'te verilmiştir. 


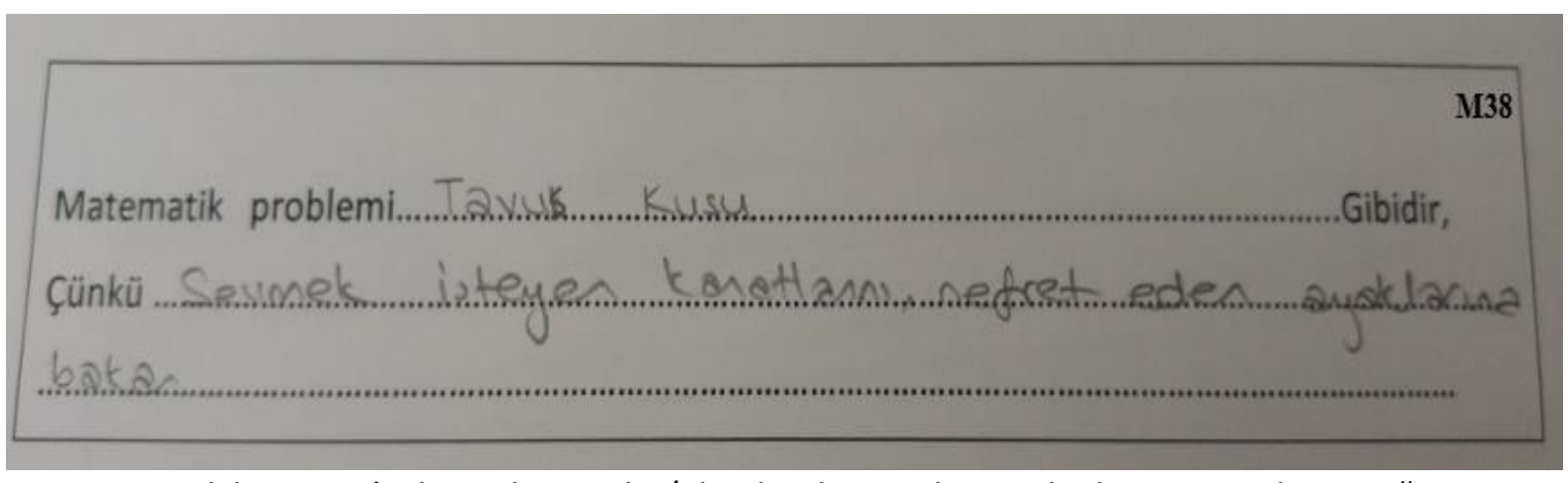

Şekil 3. M38'in karşıt kavramlar/olumlu-olumsuz kavramlar kategorisinde ürettiği metafor

Şekil 3 incelendiğinde, M38'in matematik problemini tavus kuşuna benzettiği görülmektedir. Katılımcının gerekçesi incelendiğinde, problemi seven kişilerin tavus kuşunun kanatlarını, nefret eden kişilerin de ayaklarına baktıklarını ifade ettiği anlaşılmaktadır. Bu gerekçenin daha iyi anlaşılması için öğrenciyle yapılan görüşmede araştırmacı ve katılımcı arasında geçen diyaloğa yer verilmiştir.

A: Matematik problemini tavus kuşuna benzetmişsin. Neden tavus kuşuna benzettiğini detaylı olarak açıklayabilir misin?

M38: Tavus kuşu çok güzel bir kuş olmasıyla bilinir. Ancak tavus kuşunun güzelliği ayaklarıyla tamamen bir zıtlık içerisindedir. Ayakları çok çirkindir. Problemde kişiye göre değişir. Eğer matematik problemini çözmekten zevk alıyorsa problemi güzel olarak görür. Aynı tavus kuşunun güzel kanatları gibi. Aksine problem çözmekten nefret eden kişi probleme hep olumsuz bakar. Tavus kuşunun ayakları gibi çirkin gelir...

Yukarıda geçen diyalogdan anlaşılacağı üzere, katılımcının problemi tavus kuşunun güzel-çirkin olan zıt yönleriyle örtüştürdüğü bu nedenle de verdiği cevabın karşıt kavramlar/olumlu-olumsuz kavramlar kategorisinde değerlendirildiği görülmektedir.

Tablo 4. Illköğretim Matematik Öğretmenliği Programının Üçüncü Sınıfında Öğrenim Gören Öğrencilerin Probleme ilişsin Geliştirdikleri Metaforların Frekans ve Yüzde Dağııımı

\begin{tabular}{|c|c|c|c|}
\hline Sınıf Düzeyi & 3. Sinıf & & \\
\hline Kategoriler & Kodlar & f & $\%$ \\
\hline Yığılmalı yapısı / Çözüm yapısı & $\begin{array}{l}\text { Makyaj(1), Filozof(1), kolay çözülen düğüm(1), } \\
\text { bukelamun(1), satranç(1) }\end{array}$ & 5 & 19.23 \\
\hline Zor/ Karmaşık & Bulmaca(1),düğüm(1),hayat(1),öğrenci evi(1), ağaç(1) & 5 & 19.23 \\
\hline Emek/Beceri gerektirme & Dağa tırmanmak(1), bambu ağacı(1) & 2 & 7.7 \\
\hline $\begin{array}{l}\text { Karşıt kavramlar / olumlu- } \\
\text { olumsuz kavramlar }\end{array}$ & $\begin{array}{l}\text { Kahve(1), çölde su(1), sarmaşık(1), uykudan } \\
\text { uyanma(1), futbol oyunu(1), hayat (1) }\end{array}$ & 6 & 23.1 \\
\hline Korkutucu /sıkıcı/gereksiz & Labirent(1), alkol (1) & 2 & 7.7 \\
\hline Eğlenceli & Bulmaca(2) & 2 & 7.7 \\
\hline Faydalı & Su(1),güneş(1) & 2 & 7.7 \\
\hline Sonsuzluk & - & - & - \\
\hline Önemli/değerli & - & - & - \\
\hline Anlama/strateji kullanımı & Yaşamdaki sorunlar(2), & 2 & 7.7 \\
\hline $\begin{array}{l}\text { Gerçek Durum/Sık karşılaşılan } \\
\text { durumlar }\end{array}$ & - & - & - \\
\hline TOPLAM & & 26 & 100 \\
\hline
\end{tabular}

-: ilgili kategoride ve kodda metafor üretilmemiştir. 
Tablo 4'teki metaforlar incelendiğinde, üçüncü sınıf öğrencilerinin birinci ve ikinci sınıftaki öğrencilerle benzer metaforlar ürettikleri ve bu metaforların genellikle yığılmalı yapısı/çözüm yapısı, zor/karmaşık ve karşıt kavramlar kategorilerinde yoğunlaştığı görülmektedir. Diğer öğrencilerin ürettikleri metaforlar dikkate alındığında ise, emek/beceri gerektirme, korkutucu/sıkıcı/gereksiz, eğlenceli, faydalı ve anlama/strateji kullanımı kategorilerinde eşit sayıda metafor üretilmiştir. Bununla ilgili olan faydalı kategorisinde cevap veren $M 88$ 'in ve eğlenceli kategorisinde cevap veren M89'un alıntıları Şekil 4'te verilmiştir.

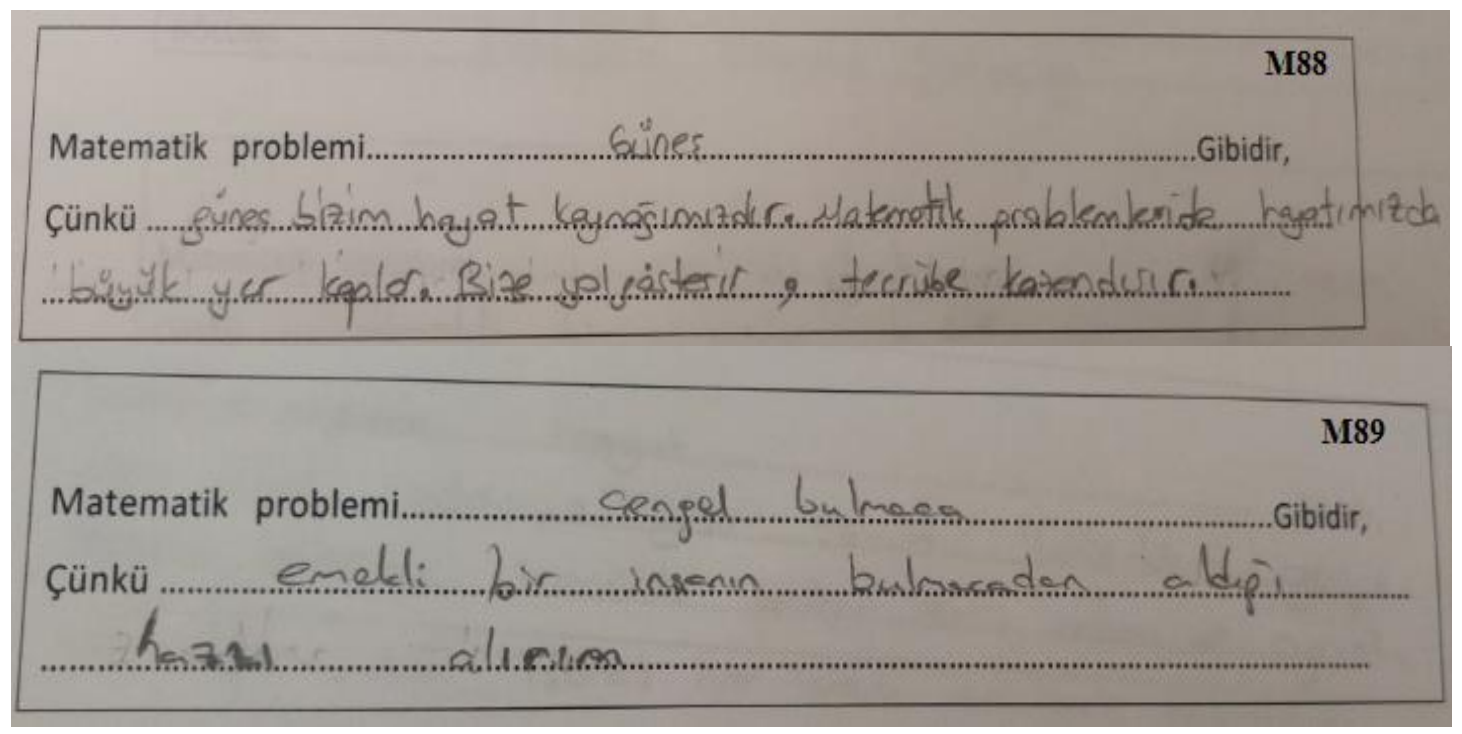

Şekil 4. M88'in ve M89'un faydalı ve eğlenceli kategorilerinde ürettikleri metaforlar

Şekil 4 incelendiğinde, katılımcılardan $M 88^{\prime}$ in problemi güneşe benzettiği ve güneşin hayat kaynağı olması özelliğinden hareketle, problemin bireye faydasından bahsetmiştir. Problemin insanlara yol gösterdiğini, tecrübe kazandırdığını ve hayatın bir parçası olduğunu dile getirmiştir. M89 da bulmacanın insana verdiği zevkten yola çıkarak problemi çengel bulmacaya benzetmiş ve problemin kendisine zevk verdiğinden bahsetmiştir. Aşağıda verilen M89 ile araştırmacı arasında geçen görüşmedeki diyaloglar bunu açıkça göstermektedir.

A: Problemi, neden çengel bulmacaya benzettin, açıklayabilir misin?

M89: Genellikle insanlar emekli olunca gazeteleri eline alıp gazetelerin ekindeki çengel bulmacayı çözerler ve bundan da keyif alırlar. Problem de benim için öyledir. Çözdükçe keyif alırım. Bulmacada kelimeler hemen aklıma gelmez ama düşünmek hoşuma gider. Problem de öyle. Çözümü hemen aklıma gelmese bile çözmeye çalışmak hoşuma gider.

Tablo 5. ilköğretim Matematik Öğretmenliği Programının Dördüncü Sınıfında Öğrenim Gören Öğrencilerin Probleme ilişkin Geliştirdikleri Metaforların Frekans ve Yüzde Dağılımı

\begin{tabular}{llll}
\hline Sınıf Düzeyi & \multicolumn{1}{c}{ 4. Sınıf } & \\
\hline Kategoriler & Kodlar & $\mathbf{f}$ & \% \\
\hline Yığılmalı yapısı / Çözüm yapısı & Hayat tecrübesi(1), puzzle(4),örümcek ağı(1), & 13 & 39.40 \\
& $\begin{array}{l}\text { Orkestra(1),meyveli pasta(1), okyanus(1), yapboz(1), } \\
\text { zeka küpü(1), yemek tarifi(1),resim(1) }\end{array}$ & \\
Zor/ Karmaşık & Labirent(1), zeka küpü(1) & 2 & 6.06 \\
Emek/Beceri gerektirme & Yapboz(1), dağ(1) & 2 & 6.06 \\
Karşıt kavramlar / olumlu- & Kördüğüm(1), söz(1) & 2 & 6.06 \\
olumsuz kavramlar & & & \\
Korkutucu /sıkıcı/gereksiz & Kedi(1) & 1 & 3.03 \\
Eğlenceli & Oyun(1),bulmaca(1),sütlü tatlı(1) & 3 & 9.09
\end{tabular}




\begin{tabular}{llll} 
Faydalı & Yaşam(1), yaşamdan bir kesit(1), harita(1), mikser(1) & 4 & 12.12 \\
Sonsuzluk & Uyku(1) & 1 & 3.03 \\
Önemli/değerli & Yaşamın kendisi(1) & 1 & 3.03 \\
Anlama/strateji kullanımı & Yemek yapma(1), şeker(1), yaşamdaki sorunlar(1) & 3 & 9.09 \\
Gerçek Durum/Sık karşılaşılan & Yaşam biçimi(1) & 1 & 3.03 \\
durumlar & & \\
\hline TOPLAM & & 33 & 100 \\
\hline
\end{tabular}

\section{-: Illgili kategoride ve kodda metafor üretilmemiştir.}

Tablo 5'e göre ilköğretim matematik öğretmenliği programının dördüncü sınıfında öğrenim gören öğrenciler, çoğunlukla yığılmalı yapısı/çözüm yapısı kategorisinde metafor üretmişler ve bu kategoride de en çok da puzzle metaforunu ifade etmişlerdir. Bununla ilgili olarak Şekil 5’te bir öğrenciden alıntıya yer verilmiştir.

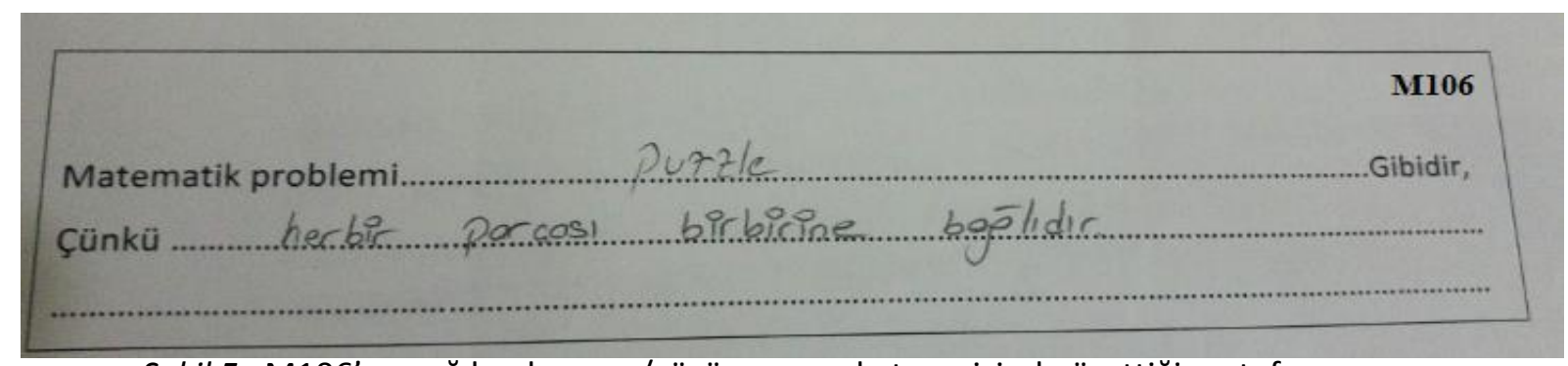

Şekil 5. M106’nın yığılmalı yapısı/çözüm yapısı kategorisinde ürettiği metafor

Şekil 5'te görüldüğü üzere katılımcının problemi puzzle nesnesine benzettiği ve gerekçe olarak problemin her bir parçasının birbirine bağlı olduğunu dile getirmiştir. Yapılan görüşmede katılımcıdan her bir parçası derken neyi kastettiğini detaylı olarak açıklaması istenmiş ve katılımcı problemin çözümündeki işlemlerin birbirine bağlı olduğunu dile getirmiştir. İşlemlerden biri yanlışsa problemin doğru sonucuna ulaşamadığını belirtmiştir. Dolayısıyla öğrencinin öne sürdüğü metafor, problemin çözüm yapısını açıkladığı için yığılmalı yapısı/çözüm yapısı kategorisinde değerlendirilmiştir. Öğrencilerin ürettikleri metaforlar dikkate alındığında diğer sınıf düzeylerinde öğrenim gören matematik öğretmenliğindeki öğrencilerle benzer metaforları ürettikleri görülmektedir. Diğer öğrencilerden (1., 2.ve 3. sınıf) farklı olarak dördüncü sınıf öğrencileri 11 farklı kategoride metafor üretebilmişlerdir. Ayrıca diğer öğrencilerin üretemediği önemli/değerli kategorisinde bir öğrenci metafor üretebilmiştir. Şekil 6'da verilen alıntı bu kategoriyi örneklendirmektedir.

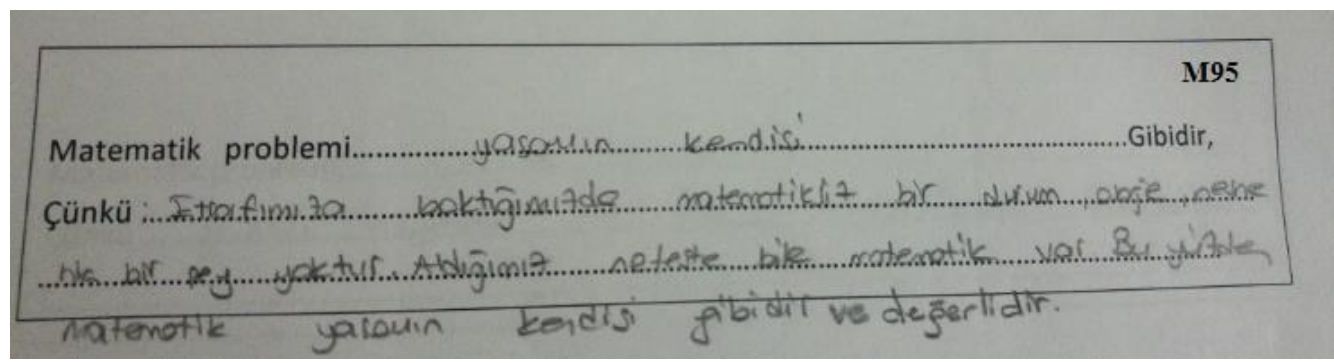

Şekil 6. M95' in önemli/değerli kategorisinde ürettiği metafor 


\section{Sınıf Öğretmenliği Programında Öğrenim Gören Öğrencilerin Geliştirdikleri Metaforlara ilişskin Bulgular}

Tablo 6. Sınıf Öğretmenliği Programının Birinci Sınıfında Öğrenim Gören Öğrencilerin Probleme Ilişkin Geliştirdikleri Metaforların Frekans ve Yüzde Dağııımı

\begin{tabular}{|c|c|c|c|}
\hline Sınıf Düzeyi & Sinıf & & \\
\hline Kategoriler & Kodlar & f & $\%$ \\
\hline Yığılmalı yapısı / Çözüm yapısı & Pizza(1), Okyanus(1),zararlı alışkanlık(1), nar(1) & 4 & 9.30 \\
\hline Zor/ Karmaşık & $\begin{array}{l}\text { Kördüğüm(1),çıkmaz sokak(1), yün yumağı(1), } \\
\text { labirent (2), insan(1), gemici düğümü(1), } \\
\text { sarmaşık(1), hint kumaşı(1) }\end{array}$ & 9 & 20.93 \\
\hline Emek/Beceri gerektirme & $\begin{array}{l}\text { Kulaklık(2), düğümlenmiş kulaklık(1), dağa } \\
\text { tırmanmak(1), karmaşık otoyollar(1) }\end{array}$ & 5 & 11.63 \\
\hline $\begin{array}{l}\text { Karşıt kavramlar / olumlu- } \\
\text { olumsuz kavramlar }\end{array}$ & Yağmurlu hava(1), sevgi(1), nar(1) & 3 & 6.98 \\
\hline Korkutucu /sıkıcı/gereksiz & $\begin{array}{l}\text { Ütü(1), bilinmezlik(1), bankada sıra bekleme(1), } \\
\text { gulyabani(1), cellat(2), kombili evde soba deliği(1), } \\
\text { kapı gıcırtısı(1), mağara(1), tilki(1), bataklık(1) }\end{array}$ & 11 & 25.58 \\
\hline Eğlenceli & Puzzle(1) & 1 & 2.32 \\
\hline Faydalı & Pazar alanı(1) & 1 & 2.32 \\
\hline Sonsuzluk & Çin seddi(1), dert(1), uzay(2) & 4 & 9.30 \\
\hline Önemli/değerli & - & - & - \\
\hline Anlama/strateji kullanımı & Hayat(2), teknolojik alet(1), kadın(1),damacana(1) & 5 & 11.63 \\
\hline $\begin{array}{l}\text { Gerçek Durum/Sık karşılaşılan } \\
\text { durumlar }\end{array}$ & - & - & - \\
\hline TOPLAM & & 43 & 100 \\
\hline
\end{tabular}

-: Illgili kategoride ve kodda metafor üretilmemiştir.

Tablo 6 incelendiğinde, sınıf öğretmenliği bölümünde öğrenim gören öğrencilerin en çok zor/karmaşık (\%20.93) ve korkutucu/sıkıcı/gereksiz (\%25.58) kategorisinde metafor ürettikleri görülmektedir. Bu iki kategoride üretilen metaforla ilgili olarak iki katılımcıdan alıntıya yer verilmiştir.

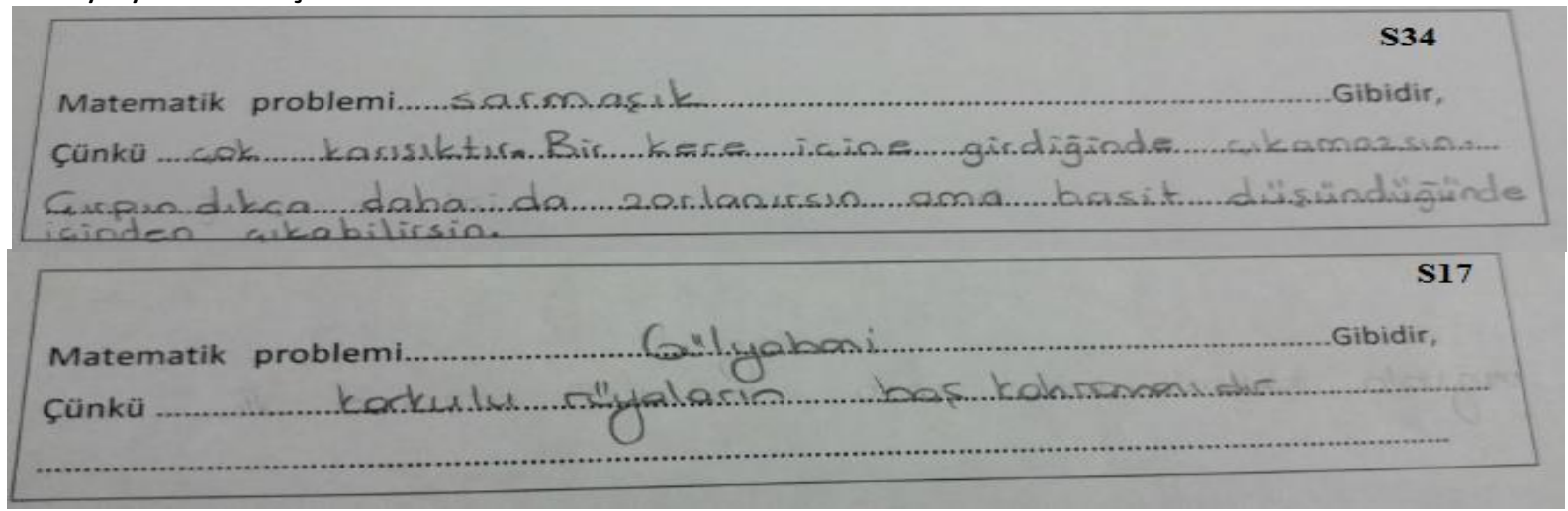

Şekil 7. S17'nin ve S34'ün zor/karmaşık ve korkutucu/sıkıcı/gereksiz kategorilerinde ürettikleri metaforlar

Şekil 7'deki öğrencilerin ürettikleri metaforlar incelendiğinde, öğrencilerin matematik problemiyle ilgili olumsuz düşüncelere sahip oldukları söylenebilir. Özellikle S17'nin matematik problemini gulyabaniye benzetmesi katılımııın problemden ne kadar korktuğunu göstermektedir. 
Tablo 7. Sınıf Öğretmenliği Programının Ikinci Sınıfında Öğrenim Gören Öğrencilerin Probleme ilişkin Geliştirdikleri Metaforların Frekans ve Yüzde Dağılımı

\begin{tabular}{|c|c|c|c|}
\hline Sınıf Düzeyi & Sinıf & & \\
\hline Kategoriler & Kodlar & f & $\%$ \\
\hline Yığılmalı yapısı / Çözüm yapısı & $\begin{array}{l}\text { Nar(1), nöronlar(1), Deney(1), denizde yüzme(1), } \\
\text { akarsu(1), roman(1), labirent(1), puzzle(1), pasta-kek(1), } \\
\text { yaşam(1) }\end{array}$ & 10 & 24.40 \\
\hline Zor/ Karmaşık & $\begin{array}{l}\text { Sevgi(1), evren(1), taranmamış saç(1), düğüm(3), } \\
\text { gemici düğümü(1), labirent(1), bulmaca(1), hayat(1), }\end{array}$ & 10 & 24.40 \\
\hline Emek/Beceri gerektirme & Yaşam(1) & 1 & 2.44 \\
\hline $\begin{array}{l}\text { Karşıt kavramlar / olumlu- } \\
\text { olumsuz kavramlar }\end{array}$ & $\begin{array}{l}\text { Şans oyunu kuponu(1), güzel ve çirkinin } \\
\text { sonsuzluğu(1),şekersiz nescafe(1) }\end{array}$ & 3 & 7.31 \\
\hline Korkutucu /sıkıcı/gereksiz & Ölüm(1),kutu(1),karamsarlık(1), hayat(1), eziyet(1) & 5 & 12.20 \\
\hline Eğlenceli & Çayın yanındaki çerez (1) & 1 & 2.44 \\
\hline Faydalı & $\mathrm{Su}(1)$ & 1 & 2.44 \\
\hline Sonsuzluk & Su(1), hayat(3), uzay(1) & 5 & 12.20 \\
\hline Önemli/değerli & - & - & - \\
\hline Anlama/strateji kullanımı & Karpuz(1),futbol(1),zeka küpü(1) & 3 & 7.31 \\
\hline $\begin{array}{l}\text { Gerçek Durum/Sık karşılaşılan } \\
\text { durumlar }\end{array}$ & Hayat $(2)$ & 2 & 4.87 \\
\hline TOPLAM & & 41 & 100 \\
\hline
\end{tabular}

\section{-: ilgili kategoride ve kodda metafor üretilmemiştir.}

Tablo 7 incelendiğinde, yapılan analiz sonucunda sınıf öğretmenliği bölümünün ikinci sınıfında öğrenim gören öğrenciler önemli/değerli kategorisi dışında 10 farklı kategoride metafor üretmişlerdir. Bu metaforlar incelendiğinde, çoğunluğunun yığılmalı yapısı/çözüm yapısı, zor/karmaşık, korkutucu/sıkıcı/gereksiz ve sonsuzluk kategorisinde olduğu görülmüştür. Emek/ beceri gerektirme, eğlenceli ve faydalı kategorisinde ise sadece bir öğrenci metafor üretmişlerdir. Karşıt kavramlar/ olumlu-olumsuz kavramlar ve anlama/strateji kullanımı kategorisinde ise üç öğrenci metafor üretmişlerdir. Anlama/strateji kullanımı kategorisinde metafor üreten katılımcılar, matematik problemini karpuz, futbol ve zeka küpüne benzeterek problemin çözülmesi için anlaşılması veya bir stratejinin belirlenmesi gerektiğini ifade etmişlerdir. Bununla ilgili olarak matematik problemini futbola benzeten katılımcının cevabı bu açıklamayı desteklemektedir.

Matematik problemi

Şekil 8. S67'nin anlama/strateji kullanımı kategorisinde ürettiği metafor 
Tablo 8. Sınıf Öğretmenliği Programının Üçüncü Sınııında Öğrenim Gören Öğrencilerin Probleme ilişkin Geliştirdikleri Metaforların Frekans ve Yüzde Dağılımı

\begin{tabular}{|c|c|c|c|}
\hline Sınıf Düzeyi & Sinıf & & \\
\hline Kategoriler & Kodlar & f & $\%$ \\
\hline YığıImalı yapısı / Çözüm yapısı & 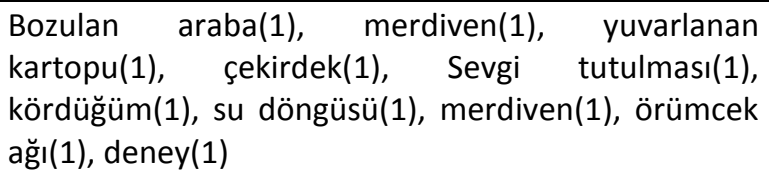 & 10 & 30.30 \\
\hline Zor/ Karmaşık & Kadın(1), dağınık oda(1), çöp(1), zararlı alışkanlık(1) & 4 & 12.12 \\
\hline Emek/Beceri gerektirme & Sevgi(2), hayat(1), kördüğüm(1) & 4 & 12.12 \\
\hline $\begin{array}{l}\text { Karşit kavramlar / olumlu- } \\
\text { olumsuz kavramlar }\end{array}$ & Bardak(1), para istemek(1), zararlı alışkanlık(1) & 3 & 9.09 \\
\hline Korkutucu /sıkıcı/gereksiz & Bataklık(2), deli(1), dar gelirli(1) & 4 & 12.12 \\
\hline Eğlenceli & Çerez(1), lunapark(1) & 2 & 6.06 \\
\hline Faydalı & - & - & - \\
\hline Sonsuzluk & Uzay(1) & 1 & 3.03 \\
\hline Önemli/değerli & Kalp(1) & 1 & 3.03 \\
\hline Anlama/strateji kullanımı & $\begin{array}{l}\text { Ankara-istanbul mesafesi (1), bilgisayar(1), ata } \\
\text { binme(1) }\end{array}$ & 3 & 9.09 \\
\hline $\begin{array}{l}\text { Gerçek Durum/Sık karşılaşılan } \\
\text { durumlar }\end{array}$ & Hayat(1) & 1 & 3.03 \\
\hline TOPLAM & & 33 & 100 \\
\hline
\end{tabular}

-: İlgili kategoride ve kodda metafor üretilmemiştir.

Yapılan analiz sonucunda, sınıf öğretmenliği üçüncü sınıf öğrencilerinin, ikinci sınıf öğrencilerle benzer metaforlar ürettikleri görülmüştür. Öğrenciler faydalı kategorisi dışında 10 farklı kategoride metafor üretmişlerdir. Bu metaforlar incelendiğinde, tüm kategoriler arasından en çok yığılmalı yapısı/çözüm yapısı (\%30.30) kategorisinde metafor üretildiği görülmüştür. Bu kategoriden sonra öğrenciler en çok zor/karmaşı, emek/beceri gerektirme ve korkutucu/sıkıcı/gereksiz kategorisinde metafor üretmişlerdir. Önemli/değerli, gerçek durum/sık karşılaşılan durum ve sonsuzluk kategorisinde ise sadece bir öğrenci metafor üretmiştir. Sonsuzluk kategorisinde metafor üreten katılımcının cevabı Şekil 9'da aynen verilmiştir.

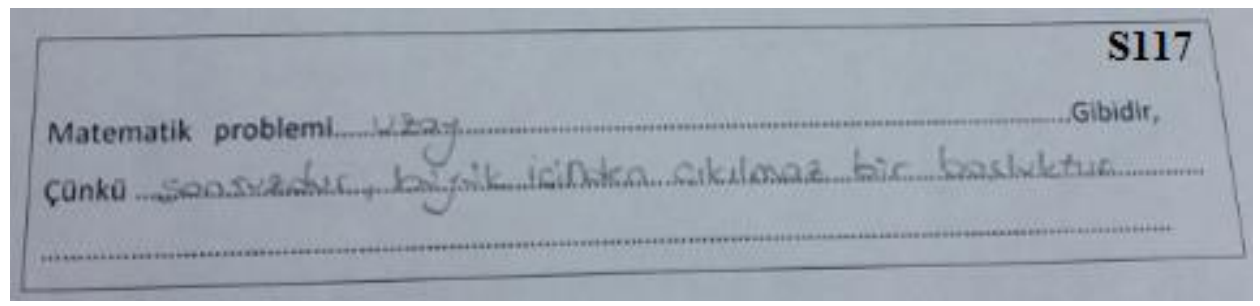

Şekil 9. S117’nin sonsuzluk kategorisinde ürettiği metafor

Şekil 9 incelendiğinde, sonsuzluk kategorisinde metafor üreten katılımcının matematik problemini uzaya benzettiği ve uzayın çıkılmaz bir boşluk oluşunu probleme yansıttığı görülmektedir. Katılımcıyla yapılan görüşmede benzer şekilde katılımcı bu açıklamasını destekleyen ifadeler kullanmıştır. 
Tablo 9. Sınıf Öğretmenliği Programının Dördüncü Sınıfında Öğrenim Gören Öğrencilerin Probleme iliş̧kin Geliştirdikleri Metaforların Frekans ve Yüzde Dağılımı

\begin{tabular}{|c|c|c|c|}
\hline Sınıf Düzeyi & 4. Sinif & & \\
\hline Kategoriler & Kodlar & $f$ & $\%$ \\
\hline Yığılmalı yapısı / Çözüm yapısı & $\begin{array}{l}\text { Şifre(1), gizemli yolculuk(1), nar(1), resim çizme(1), } \\
\text { sevgi(1), piramit(1), Sayıların doğadaki dansı(1), bakış } \\
\text { açısı(1), bulmaca(1), ilişkiler zinciri(1), hayatta } \\
\text { karşılaşılan zorluklar(1), bermuda şeytan üçgeni(1) }\end{array}$ & 12 & 60 \\
\hline Zor/ Karmaşık & Okyanus(1),kördüğüm(1), karışık kızartma(1) & 3 & 15 \\
\hline Emek/Beceri gerektirme & Yemek yapma(1), tutku(1) & 2 & 10 \\
\hline $\begin{array}{l}\text { Karşıt kavramlar / olumlu- } \\
\text { olumsuz kavramlar }\end{array}$ & - & - & - \\
\hline Korkutucu /sıkıcı/gereksiz & - & - & - \\
\hline Eğlenceli & Bulmaca(2) & 2 & 10 \\
\hline Faydalı & - & - & - \\
\hline Sonsuzluk & - & - & - \\
\hline Önemli/değerli & - & - & - \\
\hline Anlama/strateji kullanımı & Deniz(1) & 1 & 5 \\
\hline $\begin{array}{l}\text { Gerçek Durum/Sık karşılaşılan } \\
\text { durumlar }\end{array}$ & - & - & - \\
\hline TOPLAM & & 20 & 100 \\
\hline
\end{tabular}

-: Illgili kategoride ve kodda metafor üretilmemiştir.

Tablo 9 incelendiğinde, sınıf öğretmenliği dördüncü sınıf öğrencilerinin, üçüncü sınıf öğrencileri gibi en çok yığılmalı yapısı/çözüm yapısı (\%60) kategorisinde metafor geliştirdikleri görülmüştür. Diğer kategorilere bakıldığında dikkat çeken nokta korkutucu/sıkıcı/gereksiz kategorisine yer alan metafor üretilmemesidir. Birinci sınıftan dördüncü sınıfa kadar bu kategorideki metaforun sayısının azalması ve dördüncü sınıfta öğrencilerin hiçbirinin korkutucu/sıkıcı/gereksiz kategorisinde metafor üretmemesi, öğrencilerin matematik problemine karşı olumsuz görüşlerinin sınıf düzeyi arttıkça azaldığını göstermektedir. Genel olarak tüm kategoriler değerlendirildiğinde ise diğer sınıf düzeylerine göre daha az kategoride metafor ürettikleri yani 11 kategoriden 5 kategoride metafor dile getirdikleri tespit edilmiştir. Ancak bu beş kategori içinde çeşitli metaforlara yer verdikleri özellikle de yığılmalı yapısı/çözüm yapısı kategorisinde matematik problemini şifre, gizemli yolculuk, nar, resim çizme, piramit gibi çeşitli kavramlarla özdeşleştirdikleri görülmüştür. Bununla ilgili olarak S139'un alıntısına yer verilmiştir.

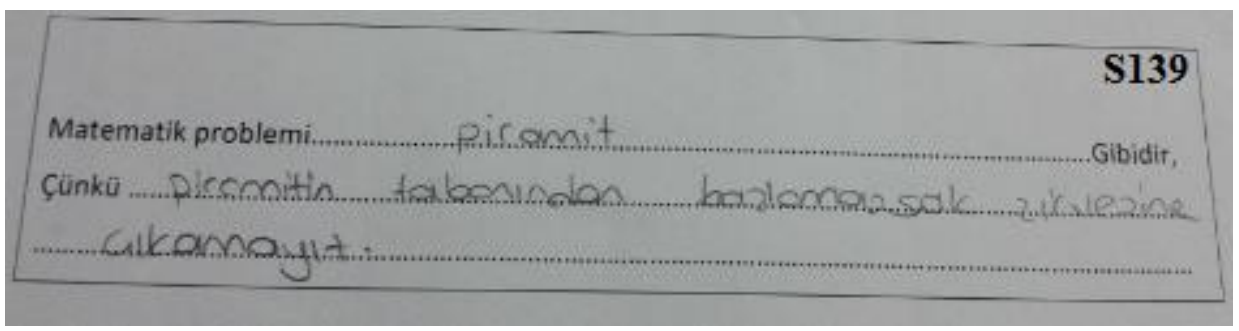

Şekil 10. S139’un yığılmalı yapısı/çözüm yapısı kategorisinde ürettiği metafor

\section{Ilköğretim Matematik ve Sınıf Öğretmenliği Programlarında Öğrenim Gören Öğrencilerin Geliştirdikleri Metaforların Karşılaştırılmasına ilişskin Bulgular}

Tablo 10. Illköğretim Matematik ve Sınıf Öğretmenliği Programında Öğrenim Gören Tüm Öğrencilerin Probleme ilişkin Geliştirdikleri Metaforların Frekans ve Yüzde Dağılımı 


\begin{tabular}{lll}
\hline KATEGORiLER & iMÖ & SÖ \\
\cline { 2 - 3 } & $\mathbf{f ( \% )}$ & $\mathbf{f ( \% )}$ \\
\hline Yığılmalı yapısı / Çözüm yapısı & $50(39.68)$ & $36(26.28)$ \\
Zor/ Karmaşık & $15(11.90)$ & $26(19.00)$ \\
Emek/Beceri gerektirme & $13(10.32)$ & $12(8.75)$ \\
Karşıt kavramlar/ olumlu-olumsuz kavramlar & $15(11.90)$ & $9(6.57)$ \\
Korkutucu /sıkıcı/gereksiz & $4(3.18)$ & $20(14.60)$ \\
Eğlenceli & $9(7.14)$ & $6(4.37)$ \\
Faydalı & $7(5.55)$ & $2(1.45)$ \\
Sonsuzluk & $3(2.38)$ & $10(7.30)$ \\
Önemli/değerli & $1(0.80)$ & $1(0.73)$ \\
Anlama/strateji kullanımı & $7(5.55)$ & $12(8.76)$ \\
Gerçek Durum/Sık karşılaşılan durumlar & $2(1.59)$ & $3(2.19)$ \\
\hline TOPLAM & $126(100)$ & $137(100)$ \\
\hline
\end{tabular}

iMÖ: ilköğretim Matematik Öğretmenliği

SÖ: Sınıf Öğretmenliği

Tablo 10 'daki veriler incelendiğinde, her iki bölümde öğrenim gören öğrencilerin matematik problemi için en çok yığılmalı ya da çözüm yapısı özelliğine vurgu yaptıkları ve bu kategoride metafor ürettikleri görülmektedir. Zor/karmaşık kategorisinde üretilen metafor sayısı dikkate alındığında ise, sınıf öğretmenliği bölümünde öğrenim gören öğrencilerin, ilköğretim matematik öğretmenliği bölümündeki öğrencilere kıyasla daha fazla sayıda metafor ifade ettikleri ortaya çıkmıştır. Bu bulgulara dayanarak sınıf öğretmenliğinde öğrenim gören öğrencilerin problemi, matematik bölümündeki öğrencilere göre daha zor algıladıkları söylenebilir. Özellikle de korkutucu/sıkıcı/gereksiz kategorisinde sınıf öğretmenliği bölümündeki öğrenciler tarafından 20 metaforun üretilmesi, öğrencilerin matematik problemiyle ilgili korkularının olduğunu ya da matematik problemini gereksiz veya sıkıcı gördüklerini göstermektedir. Faydalı ve eğlenceli kategorisi incelendiğinde, matematik öğretmenliğindeki öğrencilerin sınıf öğretmenliğindeki öğrencilere göre fazla sayıda metafor üretmesi de matematik öğretmenliğini okuyan öğrencilerin probleme karşı görüşlerinin sınıf öğretmenliğindeki öğrencilere göre daha olumlu olduğunu göstermektedir.

\section{TARTIŞMA VE SONUÇ}

Bu çalışmada, sınıf öğretmenliği ve ilköğretim matematik öğretmenliği programında öğrenim gören öğrencilerin, matematik problemini nasıl algıladıkları metafor yoluyla analiz edilmiştir. Çalışma sonunda, öğrencilerin matematik problemine ilişkin olumlu ve olumsuz metaforlar geliştirdikleri ve bu metaforların 11 farklı kategoride olduğu ortaya çıkmıştır. Bu metaforlar ayrıntılı incelendiğinde, her iki bölümde genel olarak en çok üretilen metaforun yığılmalı yapı/çözüm yapısı kategorisinde olduğu görülmüştür. illköğretim matematik öğretmenliği bölümündeki öğrencilerin problemle ilgili yığılmalı yapı/çözüm yapısı kategorisinden sonra en çok zor/karmaşık ve karşıt kavramlar/ olumlu-olumsuz kavramlar kategorilerinde yer alan metafor geliştirdikleri, sınıf öğretmenliği bölümündeki öğrencilerin ise, zor/karmaşık ve korkutucu/sıkıcı/gereksiz kategorilerinde metafor ürettikleri görülmüştür. Bu sonuç, problemin çözüm yapısı yanında bazı öğrencilerin problemi zor ve karmaşık olarak da algıladıklarını göstermektedir. Buradan her iki bölümde öğrenim gören bazı öğrencilerin problemle ilgili olumsuz düşüncelere sahip oldukları tespit edilmiştir. Benzer şekilde, alan yazında öğrencilerin matematik problemini zor ve karmaşık olarak algıladıkları pek çok çalışmaya rastlanmaktadır (Arslan \& Altun, 2007; Işık \& Kar, 2011; Özsoy, 2005; SezginMemnun, 2015; Yazgan, 2007). 
Öğrenciler, öğrenim gördükleri programa göre değerlendirildiğinde, sınıf öğretmenliği programında öğrenim gören öğrencilerin, ilköğretim matematik öğretmenliği programında öğrenim gören öğrencilere göre zor/karmaşık ve korkutucu/sıkıcı/gereksiz kategorilerinde daha fazla sayıda metafor ürettikleri tespit edilmiştir. Bu sonuç doğrultusunda, sınıf öğretmenliğinde öğrenim gören öğrencilerin matematik bölümündeki öğrencilere göre, problemi, daha zor algıladıkları ve matematik probleminden daha çok korktukları söylenebilir. Sınıf öğretmenliği bölümündeki öğrencilerin eğlenceli ve faydalı kategorilerinde az sayıda metafor üretmesi bu durumu desteklemektedir. Bu durumun nedeni olarak, sınıf öğretmenliği bölümündeki öğrencilerin, matematik problemiyle ilgili yaşantılarının, ilköğretim matematik öğretmenliği bölümündeki öğrencilere göre daha az olması gösterilebilir. Çünkü ilköğretim matematik öğretmenliği bölümündeki öğrenciler dört yıllık üniversite eğitimleri öncesinde ve sonrasında, problem çözme davranışlarıyla daha sık karşı karşıya kalmaktadır. Fitzpatrick (1994) bu açıklamayı desteklemekte ve kişilerin matematik problemine bakış açılarının, inançlarından ve geçmiş yaşantılarından etkilenebileceğini ifade etmiştir. Benzer şekilde Öztürk (2007), üniversite eğitimi alan öğrencilerin ön öğrenmelerinin öğrenim gördükleri üniversite eğitimlerine yansıdığını belirterek, öğrencilerin yaşantılarından etkilendiğini ve karşılaştıkları olay, durum ve olgulara karşı yeni algılar geliştirdiklerini belirtmiştir. Bu bakımdan, öğrencilerin matematik problemiyle ilgili algılarının olumlu yönde değişmesi için öğretim elemanlarına büyük görevler düşmektedir. Bu doğrultuda, matematik probleminden korkan ya da problemi zor olarak algılayan öğrencilerin, bu algılarının ortadan kaldırılması açısından öğretim sürecinde problemin zor-karmaşık yapısından ziyade günlük yaşamdaki kullanımına, problem çözmenin önemine vurgu yapmaları ve öğrencilerin problem çözme becerilerinin gelişimi üzerine çalışmalar yapmaları önerilir.

Öğrencilerin ürettikleri metaforlar, sınıf düzeyine göre değerlendirildiğinde, tüm sınıf düzeylerinde öğrenim gören öğrencilerin benzer metaforlar geliştirdikleri göze çarpmaktadır. Önemli görülen sonuçlardan biri, matematik problemini zor/karmaşık ya da korkutucu/sıkıcı/gereksiz olan metafor sayısının son sınıfta en aza inmesidir. Bunun sebebi olarak, öğrencilerin üniversitede aldıkları eğitim yaşantıları gösterilebilir. Özellikle sınıf öğretmenliği bölümündeki öğrencilerin birinci ve ikinci sınıfta her iki kategoride fazla metafor üretmesi ve dördüncü sınıfta korkutucu/sıkıcı/gereksiz kategorisinde metafor çıkmaması bu açıklamayı desteklemektedir.

Bu çalışma, ilköğretim matematik ve sınıf öğretmenliği programında öğrenim gören öğrenciler ile yürütülmüştür. Bu alanda çalışma yapacak olan araştırmacılar, öğretmenler ile benzer çalışma yaparak, sınıf ve matematik öğretmenlerinin problemi nasıl algıladıklarını metafor yoluyla inceleyebilirler. Çünkü metafor, bireylerin algılarını ortaya çıkarmak için etkili bir araçtır (Arnett, 1999). Lakoff ve Johnson (2005) da metaforun insanların algılayışının bir şekli olarak ifade etmiştir. Yine bu alanda çalışma yapacak olan araştırmacılar, benzer çalışmayı lise öğrencileri ile yürütebilirler. Ayrıca öğretmenlerin ve öğretmen adaylarının matematik problemine ilişkin metaforlarını inceleyen karşılaştırmalı çalışmalara yer verilebilir. 


\section{KAYNAKÇA}

Ada, S. (2013). Öğrencilerin matematik dersine ve matematik öğretmenine yönelik algılarının metafor yardımıyla belirlenmesi.Yayımlanmamış yüksek lisans tezi, Gazi Üniversitesi Eğitim Bilimleri Enstitüsü, Ankara.

Akkaya, E. (2012). Ortaöğretim öğrenci ve öğretmenlerin okul ve ideal okul algılarının metafor yoluyla analizi. Yayınlanmamış doktora tezi, Gazi Üniversitesi Eğitim Bilimleri Enstitüsü, Ankara.

Aktürk, A. O., Mihçi, S., \& Çelik, i. (2015). Metaphors of high school students about the concept of "interactive whiteboard". International Journal of Education in Mathematics, Science and Technology, 3(2), 120-131.

Arnett, R. C. (1999). Metaphorical guidance: Administration as building and renovation. Journal of Educational Administration, 37, 80-90.

Arslan, M. M. \& Bayrakçı, M. (2006). Metaforik düşünme ve öğrenme yaklaşımının eğitimöğretim açısından incelenmesi. Milli Eğitim, 35(171), 100-108.

Arslan, Ç. \& Altun, M. (2007). Learning to solve non-routine mathematical problems. ilköğretim Online, 6(1), 50-61.

Balcı, A. (1999). Metaphorical images of school: School perceptions of students, teachers and parents from four selected schools (in Ankara). Yayımlanmamış doktora tezi, Orta Doğu Teknik Üniversitesi Sosyal Bilimler Enstitüsü, Ankara.

Balcı, A. (2003). Eğitim örgütlerinde yeni bakış açıları: kuram-araştırma ilişkisi. Kuram ve Uygulamada Eğitim Yönetimi, 33, 26-61.

Baş, F. \& Özturan-Sağırlı, M. (2016). Ortaokul matematik öğretmen adaylarının problem kavramına ilişkin algıları üzerine bir inceleme. International Journal of Human Sciences, 13(1), 1367-1380. doi:10.14687/ijhs.v13i1.3461

Baykul, Y. (2009). Ortaokulda matematik öğretimi (5-8. Sınıflar) (2. Baskı). Ankara: Pegem Akademi

Baykul, Y. \& Sulak, S. (2006). Problem çözme stratejilerinin ilköğretimde problem çözme başarısına etkisi. Ulusal Sını Öğretmenliği Kongresi Bildiri Kitabı, Ankara.

Bloom, W. \& Niss, M. (1991). Applied mathematical problem solving, modelling, applicationsnand links to other subjects. Educational Studies in Mathematics, 22, 3768.

Brown, N. M. (2003). A study of elementary teachers' abilities, attitudes, and beliefs about problem solving. Dissertation Abstracts International, 64(10), 3620. (UMI No. 3108818).

Cai, J. (2003). Singaporean students' mathematical thinking in problem solving and problem posing: an exploratory study. International Journal of Mathematical Education in Science and Technology, 34(5), 719-737.

Cerit, Y. (2008). Öğretmen kavramı ile ilgili metaforlara ilişkin öğrenci, öğretmen ve yöneticilerin görüşleri, Türk Eğitim Bilimleri Dergisi, 6(4), 693-712.

Chapman, O. (1997). Metaphors in the teaching of mathematical problem solving. Educational Studies in Mathematics, 32(3), 210-228. 
Chapman, O. (1998). Metaphors as a tool in facilitating preservice teacher development in mathematical problem solving. In A. Oliver \& K. Newstead (eds.) Proceedings of the 22nd PME International Conference. Stellenbosch, South Africa: University of Stellenbosch, (2) 176-183

Crespo, S. (2003). Learning to pose matematical problems: Exploring changes in preservice teachers' practices. Educational Studies in Mathematics, 52, 243-270.

Crespo, S. \& Sinclair, N. (2008). What makes a problem mathematically interesting? Inviting prospective teachers to pose better problems. Journal Mathematics Teacher Education, 11, 395-415.

Çekmez, E., Yıldız, C., \& Bütüner, S. Ö. (2012). Fenomenografik araştırma yöntemi. Necatibey Eğitim Fakültesi Elektronik Fen ve Matematik Eğitimi Dergisi (EFMED), 6(2), 77-102.

Çelik, D. \& Güler, M. (2013). Illköğretim 6. sınıf öğrencilerinin gerçek yaşam problemlerini çözme becerilerinin incelenmesi. Dicle Üniversitesi Ziya Gökalp Eğitim Fakültesi Dergisi, 20, 180-195.

Dinç-Artut, P. \& Tarım, K. (2009). Öğretmen adaylarının rutin olmayan sözel problemleri çözme süreçlerinin incelenmesi. Uludağ Üniversitesi Eğitim Fakültesi dergisi 22(1), 53-70.

Fitzpatrick, C. (1994). Adolescent mathematical problem solving: The role of metacognition, strategies and beliefs. Paper presented at the Annual Meeting of the American Education Research Association, New Orleans, La.

Forcenville, C. (2002). The identification of target and source in pictorial metaphors. Journal of Pragmatics, 34, 1-14.

Gail, M. (1996). Problem solving about problem solving: framing a research agenda. Proceedings of the Annual National Educational Computing Conference, Minnesota, 17, 255-261.

Gökkurt, B., Örnek, T., Hayat, F., \& Soylu, Y. (2015). Öğrencilerin problem çözme ve problem kurma becerilerinin değerlendirilmesi. Bartın Üniversitesi Ĕ̆itim Fakültesi Dergisi, 4(2), 751-774.

Gökkurt, B., Koçak, M., \& Soylu, Y. (2015,Mayıs). ilköğretim matematik öğretmeni adaylarının sözel problemleri değişkensiz çözebilme becerileri. 2. Türk Bilgisayar ve Matematik Eğitimi Sempozyumunda sunulan sözlü bildiri. Adıyaman: Adıyaman Üniversitesi.

Gökkurt, B. \& Soylu, Y. (2013). Öğrencilerin problem çözme sürecinde anlam bilgisini kullanma düzeyleri. Kastamonu Üniversitesi Eğitim Fakültesi Dergisi, 21(2), 469-488.

Güler, G., Akgün, L., Öçal, M. F., \& Doruk, M. (2012). Matematik öğretmeni adaylarının matematik kavramına ilişkin sahip oldukları metaforlar. Eğitim ve Öğretim Araştırmaları Dergisi, 1(2), 25-29.

Güler, G., Öçal, M. F., \& Akgün, L. (2011). Pre-service mathematics teachers' metaphors about mathematics teacher concept. Procedia Social and Behavioral Sciences, 15, 327-330.

Gür, H., Hangül, T., \& Kara, A. (2014). Ortaokul ve lise öğrencilerinin "matematik" kavramına ilişkin sahip oldukları metaforların karşılaştırılması. The Journal of Academic Social Science Studies, 25, 427-444.

Işık, C. \& Kar, T. (2011). Ilköğretim 6, 7 ve 8. sınıf öğrencilerinin sayı algılama ve rutin olmayan problem çözme becerilerinin incelenmesi. Ahi Evran Üniversitesi Eğitim Fakültesi Dergisi, 12(1), 57-72. 
Karadeniz, O., Er, H., \& Tangülü, Z. (2014). 8. sınıf öğrencilerinin SBS' ye yönelik metaforik algıları. Uluslararası Avrasya Sosyal Bilimler Dergisi, 5(15), 64-81.

Kılıç, Ç. (2014). Sınıf öğretmenlerinin problem kurmayı algılayış biçimlerinin belirlenmesi. Kastamonu Eğitim Dergisi, 22(1), 203-214.

Lakoff, G. \& Johnson, M. (2005). Metaforlar hayat, anlam ve dil. (Çev: G. Y. Demir). İstanbul: Paradigma Yayınları.

Lester, F. K. (1983). Trends and issues in mathematical problem-solving research. In R. Lesh \& M. Landau (Eds.), Acquisition of mathematics concepts and processes (pp. 229-261). New York: Academic Press.

Mcmillian, H. J. \& Schumacher, S. (2010). Research in education. Boston, USA: Pearson Education.

Miles, M.B. \& Huberman, A. M. (1994). Qualitative data analysis (2. Baskı).Newbury Park, CA: Sage.

Milli Eğitim Bakanlığı [MEB], (2013a). Ortaokul matematik dersi (5, 6, 7 ve 8. Sınıflar) sınıflar öğretim programı ve kılavuzu. Ankara: Ankara: Talim ve Terbiye Kurulu Başkanlığı

Milli Eğitim Bakanlığı [MEB], (2013b). Ortaöğretim matematik dersi (9, 10, 11 ve 12. Sınıflar) sınıflar öğretim programı ve kılavuzu. Ankara: Talim ve Terbiye Kurulu Başkanlığı.

Milli Eğitim Bakanlığı [MEB], (2015). Ilkokul matematik dersi (1, 2, 3 ve 4. Sınıflar) sınıflar öğretim programı ve kılavuzu. Ankara: Talim ve Terbiye Kurulu Başkanlığı.

Olkun, S. \& Toluk-Uçar Z. (2014). ilköğretimde etkinlik temelli matematik öğretimi (6. Baskı). Ankara: Eğiten Kitap.

Olkun, S., Şahin, Ö., Akkurt, Z., Dikkartın, F. T., \& Gülbağcı, H. (2009). Modelleme yoluyla problem çözme ve genelleme: ilköğretim öğrencileriyle bir çalışma. Eğitim ve Bilim, 34(151), 65-73.

Özdemir, S. \& Akkaya, E. (2013). Genel lise öğrenci ve öğretmenlerinin okul ve ideal okul algılarının metafor yoluyla analizi. Kuram ve Uygulamada Eğitim Yönetimi, 19(2), 295322.

Özsoy, G. (2005). Problem çözme becerisi ile matematik başarısı arasındaki ilişki. Gazi Eğitim Fakültesi 25(3), 179-190.

Öztürk, Ç. (2007). Sosyal bilgiler, sınıf ve fen bilgisi öğretmen adaylarının "coğrafya" kavramına yönelik metafor durumları. Ahi Evran Kırşehir Eğitim Fakültesi Dergisi (KEFAD), 8(2), 5569.

Pesen, C. (2003). Eğitim fakülteleri ve sınıf öğretmenleri için matematik öğretimi. Ankara: Nobel Yayın Dağıtım.

Saban, A. (2004). Giriş düzeyindeki sınıf öğretmeni adaylarının "öğretmen” kavramına ilişkin ileri sürdükleri metaforlar, Türk Eğitim Bilimleri Dergisi, 2(2), 131-155.

Sart, G. (2015). Fenomenoloji ve yorumlayıcı fenomenolojik analiz. F. N. Seggie \& Y. Bayyurt (Edt.), Nitel araştırma yöntem, teknik, analiz ve yaklaşımları (1. Baskı). Ankara: Anı Yayıncilık. 
Sezgin-Memnun, D. (2015). Ortaokul öğrencilerinin matematik problemine ilişkin sahip oldukları metaforlar ve bu metaforların sınıf düzeylerine göre değişimi. Necatibey Eğitim Fakültesi Elektronik Fen ve Matematik Eğitimi Dergisi(EFMED), 9(1), 351-374.

Şengül, S. \& Katrancı, Y. (2012). İlköğretim ikinci kademe öğrencilerinin "matematik" kavramına ilişkin sahip oldukları metaforlar. Eğitim ve Öğretim Araştırmaları Dergisi, 1(4), 355369.

Şengül, S., Katrancı, Y., \& Gerez-Cantimer, G. (2014). Ortaokul öğrencilerinin “matematik öğretmeni" kavramına ilişkin metafor algıları. The Journal of Academic Social Science Studies, 25, 89-21.

Willoughby, S. S. (1985). How to teach mathematical problem-solving. Educational Leadership, 42(7), 90-91.

Yazgan, Y. (2007). Dördüncü ve beşinci sınıf öğrencilerinin rutin olmayan problem çözme stratejileriyle ilgili gözlemler. Ilköğretim Online, 6(2), 249-263.

Yıldııım, A., Hacıhasanoğlu, R., Karakurt, P., \& Türkleş, S. (2011). Lise öğrencilerinin problem çözme becerileri ve etkileyen faktörler. Uluslararası insan Bilimleri Dergisi, 8(1), 904921.

Yıldırım, A. \& Şimşek, H. (2013). Sosyal bilimlerde nitel araştırma yöntemleri (9. Baskı). Ankara: Seçkin Yayıncılık. 


\section{SUMMARY}

In mathematics teaching program, problem solving takes an important place (Baykul \& Sulak, 2006) and it takes the place in the aims and objectives of mathematics lesson (Baykul, 2009). Problem solving must not only be considered as the solution of a mathematics problem but it also is understood as finding beneficial solutions for new situations in case of facing with these situations (Gail, 1996). Özsoy (2005) explains the problem as a situation having complex or unclear result in general perspective. Lester (1983) also expresses the problem as the situations that the individuals need solution or want the solutions. In the present study, the concept of the problem is considered as the mathematics problem based on the purpose of it.

The views of the individuals about mathematics problem are affected by their own beliefs and past experiences (Fitzpatrick, 1994). The individuals' approaches related to mathematics problem differentiate (Yıldırım, Hacıhasanoğlu, Karakurt, \& Türkleş, 2011). In this respect, it is important to identify positive and negative thoughts of the students related to mathematics problem. One of the most useful ways to represent the individuals' views about problem is their metaphors since they are one of the most powerful mental media to reflect and direct the individuals' thought about phenomena (Saban, 2004). Metaphors are used to express the unknown events and making these events known by assimilations (Balcl, 2003). In the current study, it was aimed to identify the metaphors of the preservice primary school teachers and the preservice middle school mathematics teachers about mathematics problem and to examine the variation of these metaphors based on their grade levels and subject area.

The form designed by Sezgin-Memnun (2015) about mathematics problem was used as the instrument to collect data in the study. The participants of the study were composed of 269 (204 female, 65 male) students enrolled in the programs of elementary mathematics education and primary education at a university in North West part of Turkey. The data were collected through the written descriptions of the participants about this form and the interviews made by 16 participants. The study was designed based on phenomenology as a qualitative research method. The data were analyzed based content and descriptive analysis techniques. At the end of the study, it was observed that the participants formed 11 different categories of metaphors about mathematics problem and the most commonly formed metaphor was cumulative structure/solution structure. Moreover, it was found that the perception of the participant at the program of primary education formed more negative views than the participants at the program of elementary mathematics education.

When the metaphors formed by the preservice teachers in the study were examined based on their grade levels, it was observed that the preservice teachers at the same grade level produced similar metaphors. One of the important finding is that the number of the preservice teachers providing the metaphor of difficult/complex or scary/boring/unnecessary for mathematics problem has decreased for the last grade level or senior preservice teachers. The reason of this case might be the education taken and the experiences attained by them in their departments. Especially the finding that freshmen and sophomore preservice primary school teachers produced many metaphors about both categories and senior preservice preservice teachers did not provide scary/boring/unnecessary metaphor encourage this expression.

The present study was conducted to the preservice primary school teachers and middle school mathematics teachers. The researchers can conduct the similar study to the inservice the primary school teachers and middle school mathematics teachers in order to examine their metaphors about mathematics problem since the metaphors are effective to identify the individuals' views (Arnett, 1999). The similar study can also be conducted to the high school students. Moreover, the studies comparing the metaphors about mathematics problem formed by inservice and preservice teachers. 